\title{
Potential Application of Hybrid Renewable Energy Systems in Aquafarms of Veracruz, Mexico
}

\author{
F.J. Gómez ${ }^{1}$, I. Valencia ${ }^{1}$ and A. Pérez-Navarro ${ }^{2}$ \\ ${ }^{1}$ Department of Electrical and Electronics Engineering \\ Instituto Tecnológico de Veracruz \\ Miguel Ángel de Quevedo 2779, 91860 Veracruz (Mexico) \\ Phone/Fax number: +52 229 9341500, e-mail: fjgomezg@itver.edu.mx, ivvasa@itver.edu.mx \\ ${ }^{2}$ Institute for Energy Engineering \\ Universidad Politécnica de Valencia \\ Camino de Vera s/n, 46022 Valencia (Spain) \\ Phone/Fax number: +34 963877270, e-mail: anavarro@iie.upv.es
}

\begin{abstract}
This paper reviews the existing legal framework in Mexico to promote the use of renewable energy in aquaculture activities.

An analysis of the potential of renewable energy available in the state of Veracruz is also made, such as wind, solar and biomass, in order to determine its feasibility in the design of hybrid renewable energy systems (HRES) applied to aquafarms in the central coastal region central of such state.

It was found that SAGARPA (Secretaría de Agricultura, Ganadería, Desarrollo Rural, Pesca y Alimentación) has a specific program for the implementation of renewable energy in the agricultural sector.

Moreover, the possible application of HRES in aquafarms of Veracruz is feasible and recommended for reduction in costs relative to energy consumption.
\end{abstract}

\section{Key words}

Hybrid Renewable Energy System, Aquafarms, Renewable Resources.

\section{Introduction}

The interest of this work focuses on the opportunity presented by the possible application of Hybrid Renewable Energy Systems (HRES) in a little explored field, that of aquafarms.

The aquaculture in Mexico is one of the most important primary activities for counteracting the food needs of a large part of the population. In this sense, the state of Veracruz is emerging as a great platform to trigger the aquaculture activities in the country.
Nevertheless, in aquafarms the power consumption costs usually are high, so the feasible application of HRES in this sector could help to reduce such costs.

On the other hand, Mexico has an undeniable potential for renewable energy, with a variety of resources such as wind, solar, geothermal, biomass and hydro. So, if the potential of renewable resources in that region is suitable, its use in the design of HRES applied to aquafarms would be feasible.

Since in Mexico there are programs like [23], among others regulatory frames which promote the use of renewable energy, its necessary to make a revision of such instruments and their possible involvement in aquafarms located in the central coastal region of the state of Veracruz and mainly dedicated to raising tilapia and shrimp.

\section{Materials and methodology}

The methodology is based in the achievement of the following objectives:

a) Analyse the policies and programs implemented by the Mexican government for the renewable energies application in aquaculture activities, aquafarms specifically.

b) Perform a revision of renewable resource potential available in the coastal central region of the State of Veracruz, such as wind, solar and biomass.

c) Evaluate the potential of resources available in the region under study and their possible integration in a HRES design. 


\section{A. Concept of aquaculture.}

Aquaculture means every kind of culture of aquatic animals and plants in fresh, brackish or sea water. It refers to the use of methods and techniques for the management and control of organisms whose habitat is water, until their harvest, processing, marketing and consumption [16].

Fishery and aquaculture products represent an important option in the National Crusade against Hunger promoted by the Mexican government.

The average annual fishery and aquaculture production in Veracruz is about 70940 tons, of which $43.4 \%$ is relative to aquaculture, equivalent to 1185 million pesos $\left(4^{\text {th }}\right.$ national place) [7].

In the state of Veracruz, the aquafarms are mostly concentrated in an area of 70 kilometers radius taking as center the Port of Veracruz and even the areas of the Tuxtlas and Martinez de la Torre, at north [17].

According to CONAPESCA (Comisión Nacional de Acuacultura y Pesca), by 2014 there were 1500 registered aquafarms in the state of Veracruz that generated jobs and benefits for thousands of families [19].

One of the most important aquafarms, known as "La Capilla", is located at kilometer 40 of the federal highway Veracruz-Córdoba. See figure 1.

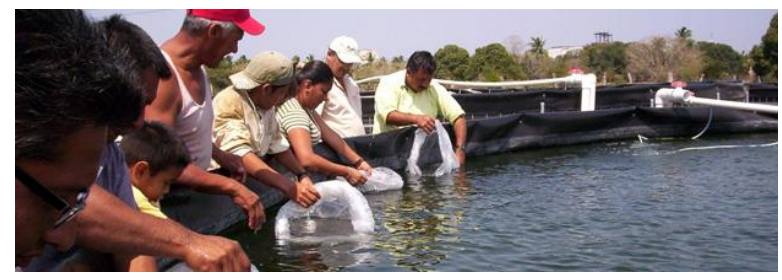

Figure 1.- Image of the aquafarm "La Capilla"

B. Legal framework.

The SENER (Secretaría de Energía) presents in [1] the legal framework and enumerates the impact in renewable energy of the following instruments:

1. Ley de Transición Energética (LTE), approved in December 2015. It abrogates the Ley para el Aprovechamiento Sustentable de la Energía LASE) and the Ley para el Aprovechamiento de las Energías Renovables y el Financiamiento de la Transición Energética (LAERFTE).

2. Ley de la Industria Eléctrica (LIE).

3. Ley de Energía Geotérmica (LEG).

4. Ley General de Cambio Climático (LGCC).

5. Reglamento Interior de la Secretaría de Energía.

6. Ley de Promoción y Desarrollo de los Biocombustibles.

7. Ley de los Órganos Reguladores Coordinados en Materia Energética.
Nowadays, Mexico has several instruments dedicated to promote the application of renewable energies in electricity generation, water warming and transport as biofuel.

Planning instruments include:

1. La Estrategia Nacional de Energía 2013-2027 (ENE).

2. La Estrategia Nacional de Transición Energética y Aprovechamiento Sustentable de la Energía (ENTEASE).

3. La Estrategia de Transición para Promover el Uso de Tecnologías más Limpias.

4. El Programa Sectorial de Energía 2013-2018 (PROSENER).

5. El Programa Especial para el Aprovechamiento de Energías Renovables 2014-2018 (PEAER).

6. El Programa de Desarrollo del Sistema Eléctrico Nacional 2015-2029 (PRODESEN).

7. El Programa Estratégico de Formación de Recursos Humanos en Materia Energética (PEFRHME).

8. La Comisión Intersecretarial de Bioenergéticos (CIB).

Economical instruments include:

1. Certificados de Energías Limpias (CEL).

2. Subasta de Largo Plazo para Potencia, Energía y CEL.

3. Cuenta de Utilidad por Inversión en Energías Renovables.

4. Fondo para la Transición Energética y el Aprovechamiento Sustentable de la Energía (FOTEASE).

5. Fondo de Sustentabilidad Energética.

6. Fondo de Servicio Universal Eléctrico.

7. Unidad de Contenido Nacional y Fomento de las Cadenas Productivas e Inversión en el Sector Energético.

Promotion, research, improvement, and innovation for renewable energies instruments are including:

1. Centros Mexicanos de Innovación en Energía (CEMIEs).

2. Inventario Nacional de Energías Limpias.

3. Atlas Nacional con Alto Potencial de Energías Limpias.

4. Ventanilla de Proyectos de Energías Renovables (VER).

\section{Renewable resource potential.}

According to the U.S. Energy Information Administration, Mexico's total energy consumption in 2014 consisted mostly of petroleum (45\%), followed by natural gas $(40 \%)$. Natural gas is increasingly replacing oil in electric power generation. However, because Mexico is a net importer of natural gas, higher levels of natural gas consumption will likely depend on more pipeline imports from the United States or liquefied 
natural gas (LNG) imports from other countries. All other fuel types contribute relatively small amounts to Mexico's overall energy mix. The country also has growing geothermal and wind energy capacity for electricity generation [2]. This information is shown in figure 2.

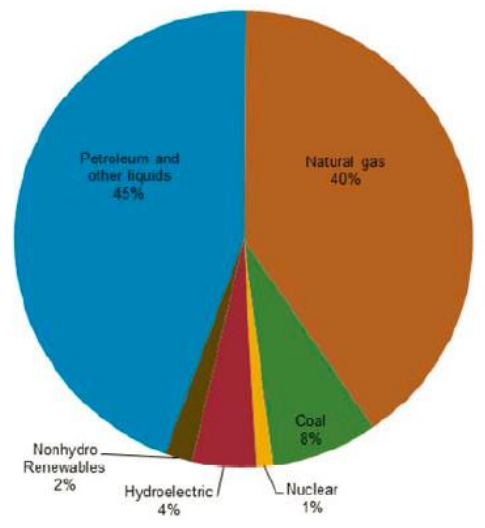

Figure 2.- 2014 Mexico's total energy consumption.

In Mexico, the state of Veracruz is located at southern of the country and borders Gulf of Mexico to the east. It can be seen in figure 3 .

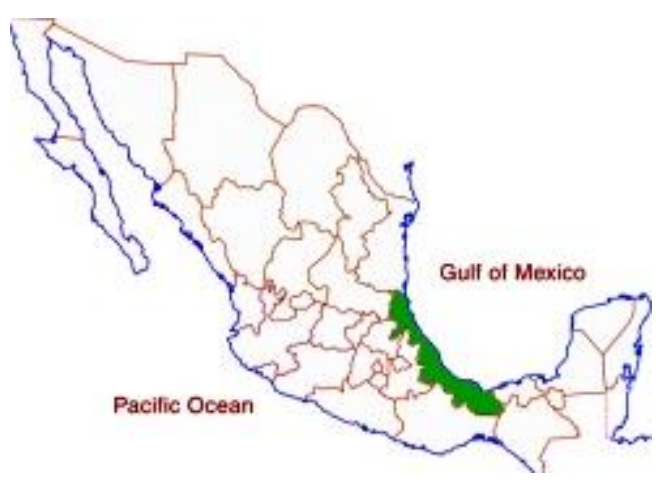

Figure 3.- Geographic location of Veracruz [3]

Mexico has several regions with very high levels of wind. Areas that have over 800 Watts/m2 are the Isthmus of Tehuantepec in Oaxaca, Tamaulipas and Baja California. Additionally to the above mentioned areas there are other several regions with high potential in Mexico [12].

The wind map of Mexico in figure 4, from the Electrical Research Institute of Mexico (IIE) shows the wind power at $80 \mathrm{~m}$ height. As can be seen, the wind potential in the coastal region of Veracruz is important.

According to [4], Veracruz not only has great potential for renewable energies to generate electricity equivalent to that produced by the Nuclear Central of Laguna Verde (located at $72 \mathrm{~km}$ northwest of the Port of Veracruz), but could be part of the solution to the energy problem across the country.

In [5] was assessed the wind speed measurements obtained in some regions of the state of Veracruz from 16 meteorological stations located at $50 \mathrm{~m}$ height. An analysis of the power generated $(\mathrm{kW})$ and energy generated
(KWh/year) using a wind turbine ACCIONA AW 70/1500 Class I is presented too.

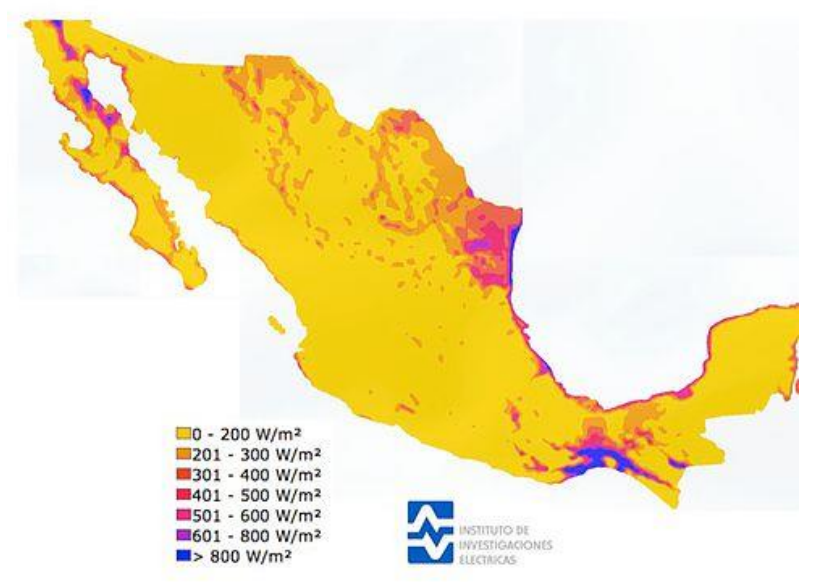

Figure 4.- Levels of wind power in Mexico [12]

The stations are property of different organizations such as the INAFAP (Instituto Nacional de Investigaciones Forestales, Agrícolas y Pecuarias), the IIE (Instituto de Investigaciones Eléctricas) and UV (Universidad Veracruzana). The results are shown in table I.

Table I.- Veracruz wind dates obtained from analysis in [5]

\begin{tabular}{|c|c|c|c|}
\hline Station & $\begin{array}{c}\text { Wind speed } \\
(\mathbf{m} / \mathbf{s})\end{array}$ & $\begin{array}{c}\text { Average } \\
\text { power } \\
\text { generated } \\
\mathbf{( k W )}\end{array}$ & $\begin{array}{c}\text { Average } \\
\text { energy } \\
\text { generated } \\
\mathbf{( k W h / y r )}\end{array}$ \\
\hline Acayucan 1 & 7.97 & 906.5 & 688,367 \\
\hline Acayucan 2 & 5.8 & 881.5 & 655,843 \\
\hline Alvarado & 6.26 & $1,029.6$ & 761,87 \\
\hline $\begin{array}{c}\text { CE INIFAP } \\
\text { Ixtacuaco }\end{array}$ & 6.33 & 964.2 & 707,362 \\
\hline Cd. Alemán & 6.82 & $1,048.8$ & 755,113 \\
\hline $\begin{array}{c}\text { Coatzacoalcos } \\
\text { UV }\end{array}$ & 6.68 & $1,028.3$ & 765,072 \\
\hline Córdoba & 6.77 & $1,034.5$ & 744,850 \\
\hline $\begin{array}{c}\text { Gutiérrez } \\
\text { Zamora }\end{array}$ & 5.9 & 981.7 & 730,411 \\
\hline ITSSAT & 5.87 & 860.3 & 619,426 \\
\hline Jalapa & 5.64 & 834.7 & 620,995 \\
\hline La Tapatía & 5.78 & 803.8 & 598,029 \\
\hline Ozuluama & 5.23 & 881.3 & 634,563 \\
\hline Paso del Macho & 5.28 & 811.8 & 604,006 \\
\hline Presa La & 5.78 & 910.5 & 698,777 \\
\hline Cangrejera & & & \\
\hline Tuxtlas & 5.85 & 723 & 545,866 \\
\hline Úrsulo Galván & 5.89 & 731.5 & 564,260 \\
\hline
\end{tabular}

In [15] it presents how the wind energy resources are characterized according to their speed on a scale that goes from class 1 to 7 , as can be seen in table II.

About solar energy, the global solar irradiation in Mexico is on average of $5 \mathrm{kWh} /$ day $/ \mathrm{m}^{2}$, but in some regions it reaches values of $6 \mathrm{kWh} /$ day / $\mathrm{m}^{2}$. Assuming an efficiency of $15 \%$, it would only take an area of $25 \mathrm{~km}^{2}$ in the desert of Sonora and Chihuahua to generate all the 
electricity the country needs today. Therefore, the technical potential is enormous [6]

Tabla II.- Wind energy resources characterization [15]

\begin{tabular}{|c|c|c|c|}
\hline Class & $\begin{array}{c}\text { Resource } \\
\text { potential } \\
(\text { commercial } \\
\text { scale })\end{array}$ & $\begin{array}{c}\text { Wind power } \\
\text { strength } \\
\left(\mathbf{W} / \mathbf{m}^{2}\right) \text { at } \\
\mathbf{5 0 m}\end{array}$ & $\begin{array}{c}\text { Wind speed } \\
(\mathbf{m} / \mathbf{s}) \text { at 50 } \\
\mathbf{m}\end{array}$ \\
\hline 1 & Poor & $0-200$ & $0.0-5.3$ \\
\hline 2 & Scarce & $200-300$ & $5.3-6.1$ \\
\hline 3 & Moderate & $300-400$ & $6.1-6.7$ \\
\hline 4 & Good & $400-500$ & $6.7-7.3$ \\
\hline 5 & Excellent & $500-600$ & $7.3-7.7$ \\
\hline 6 & Excellent & $600-800$ & $7.7-8.5$ \\
\hline 7 & Excellent & $>800$ & $>8.5$ \\
\hline \multicolumn{3}{|c}{}
\end{tabular}

Some experts rank the quality of Mexico's photovoltaic (PV) and solar thermal resources among the world's best [9]. In figure 5 it can be seen the map of global horizontal irradiation corresponding to Mexico.

In Mexico, a net-metering scheme (Medición Neta) [18] exists for PV systems below $500 \mathrm{~kW}$ mainly in the residential and commercial segments. The price of PV electricity for households with high electricity consumption is already attractive from an economic point of view since they pay more than twice the price of standard consumers. In 2013, the possibility was added for a group of neighbouring consumers (for instance in a condominium) to join together to obtain a permit to produce PV electricity. This net-metering scheme resulted in around 5000 new systems installed in 2013 [11].

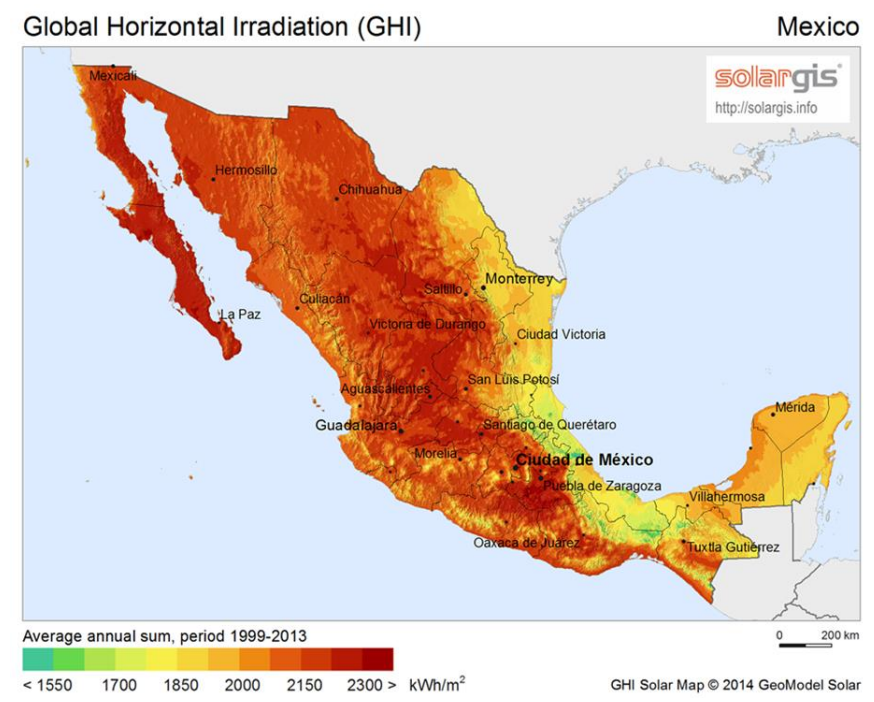

Figure 5.- Map of global horizontal irradiation in Mexico [10]

According to [8] the behavior of solar radiation in the state of Veracruz can be explained by the topography and the most important atmospheric phenomena affecting the area. A corresponding map of global solar irradiation is shown in figure 6 .

Speaking of biomass, the term is used to describe the total mass of living organic matter in a plant or in an area. The total biomass of a plant includes its bark, leaves and twigs. In a tropical forest, biomass includes every tree, shrub, sapling, vine, epiphyte and flower. About $50 \%$ of the biomass in most forests is carbon. The amount of biomass varies seasonally and is not necessarily stable over time, since plants increase their biomass as they grow [13]. The biomass density in Mexico, corresponding to trees and shrubs, can be seen in figure 7.

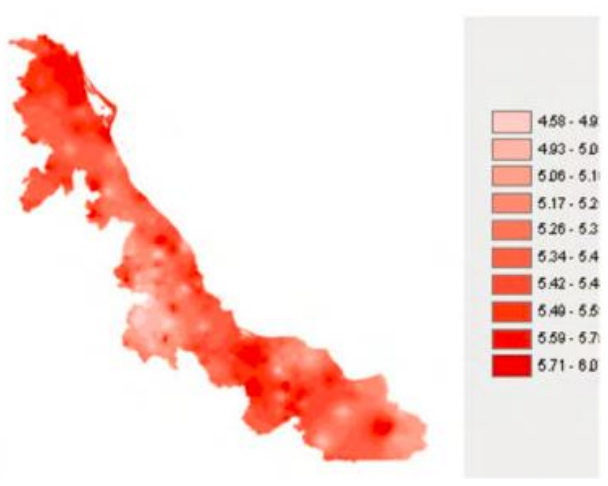

Figure 6.- Map of global solar irradiation in $\mathrm{kWh} / \mathrm{m}^{2}$ corresponding in Veracruz [8]

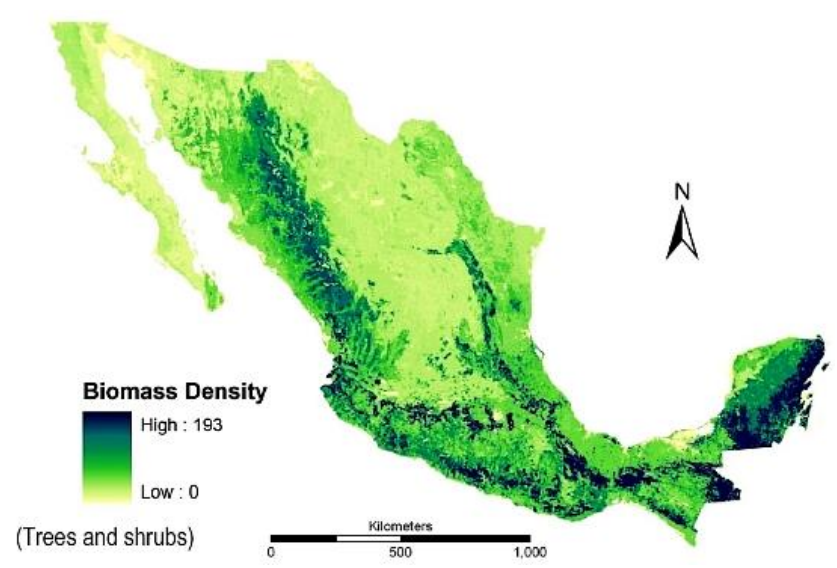

Figure 7.- Biomass density in Mexico [13]

Because of the geographical location of the state of Veracruz, it can have different sources of biomass for power generation. There is a wide variety of waste can be exploited: agricultural, manure, seaweed and water lily, which are generated in large quantities in the coast.

Seasonally, on the coast of Veracruz arrive tons of kelp, which among other things, give a bad appearance to the beaches and are annoying to bathers. If this kelp could be tapped properly as biofuel, rather than discarded, significant amounts of useful energy could be obtained. See figure 8 .

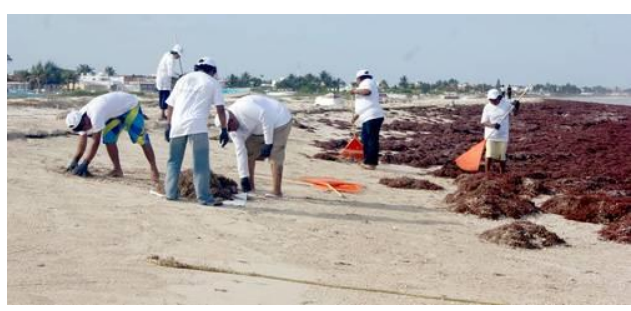

Figure 8.- Image of kelp collection 
In [14] is highlighted the potential of renewable resources existing in Mexico, such as solar, wind and biomass among others.

\section{Hybrid renewable energy system (HRES).}

Rapid depletion of fossil fuels has necessitated an urgent need for alternative sources of energy to cater the continuously increasing energy demand. Another key reason to reduce our consumption of fossil fuels is the growing global warming phenomena. Environmentally friendly power generation technologies will play an important role in future power supply. The renewable energy technologies include power generation from renewable energy sources, such as wind, PV(photovoltaic), $\mathrm{MH}$ (micro hydro), biomass, ocean wave, geothermal and tides [20].

However, common drawback with solar and wind energy is their unpredictable nature. Standalone photovoltaics (PV) or wind energy system, do not produce usable energy for considerable portion of time during the year. In general, the variations of solar and wind energy do not match with the time distribution of demand. The independent use of both the systems results in considerable over-sizing for system reliability, which in turn makes the design costly. The initial cost of solar or wind energy system is higher than diesel engine generator of comparable size but the operating and maintenance costs are always lower than that for the diesel engine generator. As the advantages of solar and wind energy systems became widely known, system designers have started looking for their integration. The term hybrid renewable energy system (HRES) is used to describe any energy system with more than one type of generator usually a conventional generator powered by diesel, and a renewable energy source such as PV, wind, and PV/wind [21].

\section{Results and discussion}

After reviewing the literature concerning the legal framework that promotes the use of renewable energy in Mexico, no evidence of specific guidance for application in aquafarms was found.

However, it attempts to raise awareness on responsible use to help reduce consumption of fossil fuels and the emission of greenhouse gases responsible for climate change effect.

The instruments establish basically, the need to define strategies for the gradual and sustained growth of the different renewable energy technologies existing in the country.

At the same time, the government of Veracruz considers relevant the application of renewable energy, especially the potential of biomass for the production of biofuels such as ethanol fuel, which Veracruz is the leading producer [7].

It was also found the SAGARPA was a pioneer in establishing a program to promote the opportunities offered by the use of renewable energy for agricultural activities, in order to identify and implement the appropriate technological applications suitable for each area of production, mainly in localities where exist adverse conditions or where it is feasible to exploit or diversify energy sources available and present the general knowledge about the characteristics and applications of renewable energy, to allow decisions on the possible implementation of a project [24].

As can be seen too, renewable resources in the state of Veracruz are varied and are present in suitable quantities for their application in electric power generation.

\section{Conclusion}

In Mexico, legal framework for the application of renewable energy is generally for any consumer and any sector; it is not specific to aquafarms.

However, since the federal government encourages the use of clean energies, they can be applied in the operation of aquafarms to help reduce electricity consumption costs.

Moreover, the state of Veracruz has a suitable potential renewable energy (wind, solar and biomass) for possible application in the design of HRES.

A HRES properly designed, can meet safely and reliably, the electricity demand of an aquafarm to help reduce the costs generated by its electricity consumption, with the understanding that the initial investment in such projects can be high.

Finally, mention that this work aims to contribute in the seeking of new solutions for satisfying the energy needs of different sectors in the region under analysis.

\section{References}

[1] SENER, "Prospectiva de Energías Renovables 2015-2029", Gobierno Federal (México, 2015), pp. 17-28.

[2] U.S. Energy Information Administration, "Mexico. Internationatl energy data and analysis", Notes (September, 21, 2015), pp. 1-14.

[3] Geo-Mexico, the geography and dynamics of modern Mexico. "Veracruz: one of Mexico's most diverse states". ISSN: 1927-1549. http://geo-mexico.com/?p=5250

[4] González Ceballos, Ángeles. “Veracruz con gran potencial para generar energías renovables en el estado y el país". (noticia). 2013.

http://www.alcalorpolitico.com/informacion/veracruz-congran-potencial-para-generar-energias-renovables-en-elestado-y-el-pais-117534.html\#.Vp5osPnhDIU

[5] Hernández-Escobedo, Q., Espinosa-Arenal, F., SaldañaFlores, R., \& Rivera-Blanco, C. (2012). "Evaluación del potencial eólico para la generación de energía eléctrica en el estado de Veracruz, México". Dyna, 79(171), 215-221. 
[6] The earth's fund. Renewable Energy. http://theearthsfund.com/energias-renovables/energiasolar/?lang=en

[7] Duarte de Ochoa, J. "V informe de gobierno. 2014-2015". Veracruz, Gobierno del Estado.

[8] Rodríguez Berlanga, M. (2014). “Concentradores solares como alternativa para satisfacer la demanda energética en el estado de Veracruz".

[9] Oseguera, Oso. (2010) "Sunny Mexico: An Energy Opportunity".

http://www.greentechmedia.com/articles/read/ sunny-mexico-an-energy-opportunity

[10] Solargis. Global Horizontal Irradiation (GHI) Mexico. http://solargis.info/doc/_pics/freemaps/1000px/ghi/SolarGISSolar-map-Mexico-en.png

[11] International Energy Agency. "Trends 2014 in photovoltaic applications”. p. 15. ISBN 978-3-906042-25-1.

[12] Grupo Eólico México. "Wind Potential in Mexico". http://www.grupoeolico.com/\#!mexico-windpotential/c182h

[13] Geo-Mexico, the geography and dynamics of modern Mexico. "Why is biomass density in Mexico relevant to climate change". ISSN: 1927-1549. http://geo-mexico.com/?p=4754

[14] Alemán-Nava, G. S., Casiano-Flores, V. H., CárdenasChávez, D. L., Díaz-Chavez, R., Scarlat, N., Mahlknecht, J., ... \& Parra, R. (2014). "Renewable energy research progress in Mexico: A review". Renewable and Sustainable Energy Reviews, 32, 140-153.

[15] Cancino-Solórzano, Y., Gutiérrez-Trashorras, A. J., \& Xiberta-Bernat, J. (2011). "Current state of wind energy in Mexico, achievements and perspectives". Renewable and Sustainable Energy Reviews, 15(8), 3552-3557.

[16] Aguilera Hernández, P, Noriega Curtis, P, \& Guzmán Chan J. ¿Qué es la acuacultura?. Secretaria de Pesca. ISBN-968-817-305-3. p. 11.

[17] Grupo Acuícola "La Capilla". "Fortalezas del Sector Acuícola en Veracruz". http://www.tilapialacapilla.com/index.php?option $=$ com_content $\&$ view $=$ article $\&$ id $=94 \&$ Itemid=73

[18] Agredano Díaz, J. (2015). Medición Neta en México. IEEE Sección Morelos.

[19] CONAPESCA (2014). "Convoca CONAPESCA a unidad y esfuerzo del sector pesquero de Veracruz para recuperar la posición productiva que antes tuvo". http://conapesca.gob.mx/wb/cona/2_de_noviembre _de_2014_veracruz

[20] Negi, S., \& Mathew, L. "Hybrid Renewable Energy System: A Review". International Journal of Electronic and Electrical Engineering. ISSN 0974-2174, Volume 7, Number 5 (2014), pp. 535-542.

[21] Deshmukh, M. K., \& Deshmukh, S. S. (2008). "Modeling of hybrid renewable energy systems". Renewable and Sustainable Energy Reviews, 12(1), 235-249.
[22] Rangel-López, L., Lango-Reynoso, F., Asian-Hoyos, A., \& del Refugio, M. (2014). "Diagnóstico de la acuacultura en el municipio de Alvarado, Veracruz, México". Ra Ximhai, 10(6), 75-81.

[23] Iniciativa Mexicana para las Energías Renovables (IMERE), World Wildfie Fund (WWF), Climate Works Fundation \& PwC. "Plan integral para el desarrollo de las energías renovables 2013-2018”.

[24] Secretaría de Agricultura, Ganadería, Desarrollo Rural, Pesca y Alimentación, Fideicomiso de Riesgo Compartido (2007). "La energía renovable en el sector agropecuario". 